\title{
Russia's commerce and navigation treaties with England, the Netherlands and Tuscany in the 1840s
}

Zarys treści: Artykuł omawia traktaty i deklaracje handlowe oraz nawigacyjne zawarte przez Rosję carską z Anglią, Holandią oraz Toskanią w latach czterdziestych XIX wieku. Pokazane też zostały przekształcenia wewnętrzne i międzynarodowe uwarunkowania prawne dotyczące prowadzenia handlu i żeglugi z Rosją przed podpisaniem rzeczonych traktatów i deklaracji. Dalsza część artykułu skupia się na treści umów rosyjsko-angielskich, holenderskich i toskańskich. W podsumowaniu poddano ocenie gospodarcze szanse rozwojowe, jakie mogło nieść ze sobą podpisanie omawianych w artykule traktatów dwustronnych.

Content outline: The present article focuses on commerce and navigation treaties and declarations concluded by Tsarist Russia with England, the Netherlands and Tuscany in the 1840s. Following a presentation of the main transformations in internal and international legal conditions governing the conduct of trade and shipping with Russia which took place before the signing of said treaties and declarations, the subsequent sections of the article detail the content of the agreements. The final part of the article discusses the economic opportunities for growth that could arise from signing the bilateral trade and shipping treaties discussed earlier.

Słowa kluczowe: Rosja, Angila, Holandia, Toskania, traktaty dwustronne, XIX wiek

Keywords: Russia, England, the Netherlands, Tuscany, bilateral treaties, $19^{\text {th }}$ century

\section{Transformations in internal and international legal conditions gover- ning the conduct of trade and shipping with Russia preceding the signing of the treaties with England, the Netherlands and Tuscany.}

The 1840s were a period of extremely intense activity by the Tsarist diplomacy in the field of establishing bilateral trade treaties with selected European countries, often renewing former ones. Such agreements, aside from the three treaties discussed in the present article, were indeed concluded by the Russian Empire around the same time (most of them even in the same year of 1846) with several 
other countries, including France, ${ }^{1}$ Austria, ${ }^{2}$ and Turkey. ${ }^{3}$ The last two are discussed by the author of the present article in a separate study.

Discussing this activity requires emphasising and correlating an unusual occurrence that might influence to some extent, only indirectly of course, the matter of British-Russian trade relations in question, namely the need to "clear the air," unquestionably required following the introduction of an absolute ban on slave trade at the beginning of the 1840s. On 8/20 December 1841 a treaty was signed in London between Russia, Great Britain, France and Prussia "on the suppression of the trade in negroes [sic]." This treaty was quickly ratified (in four copies) by Tsar Nicholas I, which took place in Sankt Petersburg on 3/15 January 1842. ${ }^{4}$ The Governing Senate in Sankt Petersburg was then obliged to issue precise regulations pertaining to the discussed issue. Along with Nicholas I's edict, the Petersburgbased newspaper Senatskie Vedomosti also published the original French and Russian text of the treaty concluded in London on 20 December 1841.

The edict stated that the Treaty of December 1841 "not only decreed the prohibition or renewal of prohibition for all subjects of the contracting parties of the trade in negroes in their possessions or under their ensigns, and of assisting this trade with one's capital or vessels, and of participating in it at all, whether directly or otherwise, but even recommended that all steps undertaken towards resuming or pursuing this trade be considered a crime equal to maritime looting and that all ships used for this purpose be deprived of the right to protection granted by the flag of that or any other contracting power."

Based on this treaty, the tsar also instructed all subjects of his empire that, from this time onwards, "everyone suspected of engaging in trade in black slaves, or of any direct or other participation in this trade, should be tried in the court of law and sentenced to punishments pertaining in our law to robbery and sea looting."

This removed the obstacle that precluded Russia (at least from a moral point of view, to which Tsar Nicholas I often referred in his actions in the international arena, at least formally) from signing a number of "modern" agreements of both commercial and navigational nature, with particular emphasis on the nations involved in such trade until then.

${ }^{1}$ F. F. Matrens, Recueil des traités et conventions conclus par la Russie avec les puissances étrangères, vol. 15: Traités avec La France, Sankt Petersburg, 1909, pp. 205-219.

2 Id., Recueil des traités et conventions conclus par la Russie avec les puissances étrangères, vol. 4, part 1: Traités avec L'Autriche 1815-1849, Sankt Petersburg, 1878, pp. 551-559.

3 The author provides a detailed description of, inter alia, the Russian-Turkish Treaty of 1846 in the article: "Handlowe i nawigacyjne konwencje rosyjskie zawarte z Turcją i Austrią w roku 1846," in: Odessa i Morze Czarne jako przestrzeń literacka, ed. J. Ławski, N. Maliutina, Białystok-Odessa, 2018, pp. 158-177.

${ }^{4}$ F. F. Martens, Recueil des traités et conventions conclus par la Russie avec les puissances étrangères, vol. 12: Traités avec l'Angleterre 1832-1895, Saint Petersbourg, 1898, pp. 170-197. The treaty was signed by: Brunnow, Koller, Ste. Aulaire, Aberdeen and Schleinitz.

5 Tygodnik Petersburski. Gazeta Rządowa Królestwa Polskiego, no. 45 of 16/28 June 1842, pp. 247-248. 
Another factor worth mentioning here is the introduction on 19 June/1 July 1845 (i.e. relatively shortly before Russia signed treaties and declarations on commerce and shipping with the Netherlands and Tuscany) of internal regulations which considerably impeded the practical conduct of trade with Russia by representatives of countries that did not enjoy the highest privileged status.

In 1845, the Tsarist authorities decided to introduce additional trade fees for vessels calling at the ports of the Russian Empire which did not come from countries that enjoyed the highest privileged status. Particularly important here were Articles 2 and 3 of the aforementioned Tsarist decree of 1 July 1845 (published a month later, i.e. on 19/31 July 1845), which imposed extraordinary taxes on such ships (based on cargo capacity measured in lasts), as well as other financial charges, referred to as "excess material fees." In practice, this regulation boiled down to levying a tax on the cargo (bulk materials, etc.) of ships from countries without preferential treatment, based on the vessels' size, set at one ruble in silver per last. The "excess material fee," on the other hand, meant paying a further 50\% of the customs duty imposed on merchant vessels from countries not benefiting from the clause described above. ${ }^{6}$ It is clear that this regulation could undoubtedly provide a direct and indirect incentive for the signing of (new) commercial and shipping agreements with Russia, which would grant mutual partners the highest privileged status.

\section{Treaty on Commerce and Shipping concluded on 30 December 1842/11 January 1843 between the Emperor of All Russia Nicholas I and the Queen of the United Kingdom of Great Britain and Ireland Victoria.}

The first of the agreements discussed here, officially called the "Treaty on Commerce and Shipping," was concluded on 30 December 1842/11 January 1843 between the Russian Tsar Nicholas I and the English Queen Victoria. Formally, the agreement was signed by the plenipotentiaries of the tsar: Minister of Foreign Affairs Karl Robert (Vasilevich) Reichsgraf von Nesselrode ${ }^{7}$ and Georg Ludwig Cancrin (Yegor Frantsevich Kankrin), who served as Minister of Finance until 1/13 May $1844 .^{8}$

${ }^{6}$ Polnoye Sobranye Zakonov Rossiyskoi Imperii, Sobranye Vtoroye, vol. 21: 1845, Sankt Petersburg, 1846, pp. 467-468; Gazeta Rządowa Królestwa Polskiego, no. 260 of 11/23 November 1847, p. 1992.

7 M. Poleskov, Nesselrode Karl (Karl Robert) Vasilievits, Rosskiy Bibliografitseskiy Slovar, Naake-Nakenskiy - Nikolai Nikolaevich Starsiy, Sankt Peterburg, 1914, p. 244. Nesselrode worked at the Ministry of Foreign Affairs from 9/21 April 1816, he was Vice Chancellor of the State from 24 March/5 April 1828, and Chancellor of the State from 17 March/29 March 1845 until 1856. He died in Sankt-Peterburg on 11/23 March 1862.

8 S. Kulibin, A. F., Kankrin Graf Yegor Francovic, Rosskiy Bibliografitseskiy Slovar, Ibak-Klucarev, Sankt Peterburg, 1897, p. 449; J. A. Lorentz, R. T. Schmitt, A. G. Volkner, Count Georg Cancrin 
The English side was represented by Baron Stuart de Rothesay (that is: Charles Stuart, $1^{\text {st }}$ Baron Stuart de Rothesay of the Isle of Bute). ${ }^{9}$

Surprisingly, Tsar Nicholas I ratified the aforementioned international agreement (with two separate articles) almost immediately, already on 2/14 January 1833. ${ }^{10}$ This haste was due to the previously expressed formal expectations. According to Article 16 of the document, the instruments of ratification of both parties were to be exchanged in London within one month of signing the agreement (i.e. by 29 January/10 February 1843 at the latest), or even earlier.

The duration of the agreement was set at ten years from its ratification (in practice almost until the end of January 1853), with an automatic extension for another twelve months, during which time one of the parties had the possibility to notify the other party of its intention to "repeal the treaty." The principle adopted was that if such a notification were to be received, the treaty itself and all its obligations would automatically cease to be in force only after a further 365 days. ${ }^{11}$

On 31 March/12 April 1843, the Governing Senate in Sankt Petersburg issued a public decree by which the original text of the Anglo-Russian agreement and its translation were publicly announced. In the official "Polish" press of the Paskevich era this treaty (or rather its first part) was published in no. 30 of Tygodnik Petersburski. Gazeta Rządowa Królestwa Polskiego [Petersburg Weekly. Government Journal of the Kingdom of Poland] of 20 April/2 May $1843 .^{12}$

Under Article 1 of the treaty, shipping and trade for vessels and subjects of both contracting parties were henceforth free of any restrictions in all their (territorial) possessions. It was clearly specified that the territories in question included those areas of English and Russian dominions where both shipping and trade were at the time, or would be in the indefinite future, considered "free" for ships and citizens of any third country. At the same time, it was decided that from the moment of the ratification of the agreement (or more precisely: from the moment of the mutual exchange of ratification instruments), English ships either calling

and the History of Cancrinite Discovery, http://www.minbook.com/site_files/16-2-en-Page24-25. pdf [accessed: 11 Jan 2019]

9 F. F. Martens, Recueil des traités..., vol. 12, p. 210; Correspondence of Sir Charles Stuart, Baron Stuart de Rothesay (1779-1845), Edinburgh University Library Special Collections, ref. GB 237 Coll-509, Administrative / Biographical History, available at: https://archiveshub.jisc.ac.uk/ search/archives/84857947-0af8-3dc0-8f71-e6a88b04e7a2 [accessed: 30 Dec 2018]; T. F. Henderson, "Rothesay Stuart Charles (1779-1845)," Dictionary of National Biography, vol. 55, London, 1898, p. 75. Baron Stewart de Rothesay served as British Ambassador Extraordinary and Plenipotentiary in Sankt Petersburg from 1841 to 1845, peer of the Parliament, Member of the Queen's Private Council, Knight of the Most Honourable Order of the Bath, and Knight of the Military Order of the Tower and of the Sword, of Valour, Loyalty and Merit (Ordem Militar da Torre e Espada do Valor, Lealdade e Mérito).

${ }^{10}$ F. F. Martens, Recueil des traités..., vol. 12, pp. 210, 223; Tygodnik..., no. 30 of 20 April/2 May 1843, p. 186.

11 Tygodnik..., no. 34 of 4/18 May 1843, p. 212.

12 Tygodnik..., no. 30 of 20 April/2 May 1843, p. 186. 
at ports of the Russian Empire or leaving those ports would not be subject to any fees or customs duties, apart from those already agreed upon for the ships of the receiving party, i.e. Russia. A similar rule applied to all Russian ships calling at ports located in the United Kingdom of Great Britain and Ireland and "in all the estates of the Most Serene Queen."

This, of course, implied further solutions, considerably facilitating Russian trade within the United Kingdom, and vice versa. Two facts were taken into account. First of all, the British ships loaded with commercial cargo could now enter Russian ports by sailing directly from countries outside the jurisdiction of the British queen and of the Russian tsar, paying only the customs duties imposed in those ports and on "domestic" vessels, i.e. Russian ships. This was connected to "the benefits which this Treaty provides [to the same extent] to English trade" conducted in the Grand Duchy of Finland.

The second solution, in turn, was related to the possibility of entering ports in Great Britain, Ireland and British dependencies by Russian ships with cargoes arriving "from the estuaries of the Vistula, Nemunas, or any other river whose tributary is a navigable river originating in the [Russian] State," or only passing through a territory leased by the Empire. These ships were now to be received at their destination ports under the same principle and with identical rights, "as if these ships were coming directly from Russian or Finnish [ports]," i.e. benefiting from all privileges and liberties guaranteed by the Russian-British Treaty on Commerce and Shipping. Moreover, Russian ships leaving British ports and areas under British control and heading for the estuaries of the Vistula and Nemunas or the other "aforementioned great rivers" were to be treated "as if" they were heading directly to the ports of the Russian Empire/Great Duchy of Finland.

It was clear, at the same time, that the continuity of the privileges thus defined, granted to Russian ships sailing from places "at the estuary [...] of great rivers," i.e. the Vistula and Nemunas, and arriving at British ports, was directly dependent on giving similar rights in the same places to English ships and their cargoes (under exactly the same conditions as applied to Russian ships). This solution, which was practically also largely dependent on the attitude of Prussia, in whose territory both these rivers flowed into the sea, was of course intended to facilitate the trade in grain from the territories of the former Commonwealth, and can be described as substantial especially for the trade in Polish and Lithuanian grain.

In principle, the Treaty of 11 January 1843 covered all agricultural crops (literally "riches of the soil," which would include minerals), as well as industrial products and works of art created in the territories of the Russian state and its dominions ${ }^{13}$ (such as the Kingdom of Poland, the Grand Duchy of Finland, or Alaska; as for Alaska itself, however, Article 12 of the Convention specified at the same time that, with regard to trade and navigation on Russian properties on the north-western

13 Tygodnik..., no. 30 of 20 April/2 May 1843, p. 186. 
shore of North America, the Convention concluded in Sankt Petersburg on 16/28 February 1825 remained in force). ${ }^{14}$ This was confirmed by the inclusion into this category of all products, crops, etc., which could be exported by means of the larger and smaller rivers indicated earlier, i.e. the Vistula and Nemunas. These goods could now be brought freely into the ports of the United Kingdom and its dependent territories. The same was true of all agricultural and industrial products and works of art exported to Russia by the British side. Trade in all these goods, etc., was to be subject to mutual and in all respects ${ }^{15}$ identical "privileges and liberties" as regards imports and exports by sea on vessels of both parties to the treaty. ${ }^{16}$

The treaty made Russian and English ships equal in their designation as means of transport of domestic origin. Namely, it was stated in Article 5 of the act that all objects, goods and crops imported into the United Kingdom, Ireland and British dependencies on Russian ships would be subject to customs duties under the same conditions as if they were introduced into the British Empire on English ships. It was therefore precisely specified that the objects in question were "all objects that were not the products of industry and art of the contracting states or their dependencies" and that came either directly from ports falling under Tsarist authority or from the so-called main (or smaller) rivers, i.e. mainly from the estuaries of the Vistula and Nemunas rivers. At the same time, goods imported from the British Empire on English ships were also to be subject solely to such customs duties as if they were imported on vessel flying the Russian ensign. To emphasise the severity and importance of the solutions thus introduced, Queen Victoria "ensured" that Russian ships and Tsarist trade-under said Article 5 of the Treaty-would enjoy all the possible benefits and privileges of the trade and shipping that were experienced at any given time, or could be experienced in the future, by representatives of the nations "enjoying privileged status." This in turn was to result from signed and ratified existing laws, parliamentary acts, judgements of the Council (the Privy Council in this context), or possibly international treaties.

Similarly, the principle of imposing customs duties on goods in Russian and British ports only as if they had been imported or exported on English or Russian ships was applied from now on to all objects, crops, etc. that were traded legally (in accordance with the provisions of the Treaty of 11 January 1843, or in accordance with the laws in force in both countries), ${ }^{17}$ "either under the English or the Russian ensign." Moreover, all objects and goods that could be legally exported from British or Russian ports on ships belonging to either contracting party were granted special premiums, the possibility of customs duty refund and other unspecified benefits.

\footnotetext{
14 Tygodnik..., no. 34 of 4/18 May 1843, p. 212.

15 Tygodnik..., no. 30 of 20 April/2 May 1843, p. 186.

16 Ibid., p. 187.

17 Tygodnik..., no. 32 of 27 April/9 May 1843, p. 186.
} 
Bilateral symmetry also applied to the storage of goods and the storage buildings themselves. Both contracting parties undertook to ensure that all objects and goods imported into British and Russian ports, and then deposited or locked in local warehouses, would be subject to exactly the same conditions, regulations and charges for the duration of their storage as if they were imported into a given port on "domestic" vessels. It was also logical that a similar solution was applied to the export process of these goods or objects; i.e. they were subject to the same procedures, regulations and charges when exported to the other party, as if these exports were carried out on their own vessels.

The January 1843 Agreement strongly emphasised the need to introduce and maintain a permanent principle of free trade in bilateral relations, based on the requirements of full free competition and absolutely unrestricted trade. It was clearly stated that neither government, nor any (trade) company, corporation or agent acting on their behalf or under their supervision had the right to grant any preference ("priority") in the purchase of crops, industrial goods and works of art incoming from "one of the two countries and their dependencies" and arriving in the ports of the other. Such decisions were also not to be influenced by the state affiliation of the vessel importing the goods in question. It therefore appeared that "it was a constant intention [...] of both contracting parties that there be no inequality or differences between the two."

Particular attention was paid to the issue of trade by Russian merchant ships in the English domains of East India. ${ }^{18}$ It turned out that Queen Victoria eventually allowed the Russian subjects to be granted identical privileges and benefits as those conferred (or guaranteed in the future) by international treaties or acts of Parliament to merchants of the so-called privileged nations conducting their business in East India. However, this also meant that the Russians engaging in trade in British India had to comply with all laws, regulations, restrictions and arrangements that were in force at that time, or to be issued in the indefinite future, with respect to ships and nationals of any other country that enjoyed privileged status when engaging in trade with British Indian domains.

Such a broadly defined treaty had its local limitations. Pursuant to Article 10 of the Agreement, the provisions of the Agreement of 11 January 1843

18 Central Archives of Historical Records, fond of the Administrative Council of the Kingdom of Poland, File 22, p. 597. Meanwhile, the trade activity conducted in East India by an "agent" of the Kingdom of Poland was practically eliminated already in 1832. The effects of trade activities conducted in India turned out to be particularly unfavourable. As a result of ill-advised speculation conducted by the Polish trade agency in that country, the treasury of the Kingdom suffered a loss of $887.537,18 \mathrm{zl}$, which amounted to a loss of $16.4 \mathrm{zl}$ per $1 \mathrm{cwt}$ of zinc sent there. In this situation, the Government Revenue and Treasury Commission in Warsaw headed by Furhmann proposed, as early as March 1832, to cease sending zinc to India. At the same time, the Polish tradesman established in Calcutta was ordered to immediately sell off all remaining zinc reserves and return to Poland. The respective decision was passed on 23 March 1832. 
were not in force in the case of coastal trade between the domestic ports of one of the contracting parties by the crews of sailing or steam vessels belonging to the other contracting party. This exclusion concerned in particular: a) all aspects of the transport of passengers, freight and objects of trade. The legislators emphasised that coastal shipping would still be reserved exclusively for ships of domestic origin.

Finally, when discussing the content of the Treaty, one more issue relating to the conduct of trade must be addressed. As already outlined above, pursuant to the commercial Treaty of 11 January 1843, the subjects and vessels of the two contracting parties (i.e. not just the goods, etc.) were finally entitled to all the benefits, liberties and privileges enjoyed within the ports of the metropoles and their dependencies by the maritime fleet and traders from the nations that enjoyed privileged status. From the British point of view, such an approach resulted directly from the practical application of the intention that, within the United Kingdom and its dependent territories, Russian vessels be able to benefit fully from the advantages of shipping and trade that had already been granted to another state with the status of a privileged nation, conferred on them by virtue of "laws, acts of Parliament, judgements of the Council, or treaties." The Russian side, on the other hand, sought to achieve a situation in which British vessels and subjects were given the right to fully enjoy, within Russian ports and possessions, the navigational and commercial privileges granted to other countries by virtue of "laws, arrangements, regulations, or treaties." Both Tsar Nicholas I and Queen Victoria also undertook to refrain from granting the subjects or nationals of any other country any new benefits, liberties or privileges in the conduct of shipping and trading with their countries and domains which would not be simultaneously granted to the subjects of either party of the treaty being signed. In two cases, such new rights and privileges had to be guaranteed at no additional charge ("without any remuneration"). Namely: a) when the granting of new benefits to a third party also occurred without any other financial burden; b) when new rights were granted with only a conditional reservation of the eventuality of fees. ${ }^{19}$

The agreement also regulated the handling of extraordinary cases. Pursuant to Article 13 of the agreement, when forced by a storm or other dangerous or unforeseen circumstances to seek shelter in ports of the other contracting party, English or Russian ships were automatically granted the right to carry out necessary repairs, purchase necessary items (or ship parts), and return to sea without having to pay any customs duty. The exception here was the requirement to cover traditional "port and lighthouse" fees, which, in such cases, should be calculated by the port authorities on the same principles as for domestic vessels. When the captain of a ship arriving in urgent need at a port of the other contracting party was forced by circumstances resulting from unexpected expenses to sell a part of

19 Tygodnik..., no. 32 of 27 April/9 May 1843, p. 201. 
goods that he was transporting, he was obliged to comply with the provisions and trade tariffs applicable at the port of call.

In the event of a disaster at sea occurring in an area under the control of the contracting parties of the Treaty of January 1843, the agreement stipulated not only that the shipwrecked receive all the assistance and support they needed, but that the goods "thrown into the sea or salvaged" be returned in full. The items and goods found at the wreck site should be retained and handed over to the injured crew at an appropriate time; however, the principle of paying the so-called "finder's fee" ("le taux de sauvetage") applied. In addition to the finder's fee, it was also necessary to pay any tariff or other financial charges imposed in such cases on goods belonging to domestic ships and on the ships themselves.

Thus, in the case of forced entry into port or a disaster at sea, the representatives of the injured party, i.e. consuls, vice-consuls, or commercial agents would be granted the required rights to formally apply for the assistance needed by their peers. It is also worth noting that the last of the fourteen points of the main part of the Treaty of 11 January 1843 addressed the rather sensitive issue of deserters. Indeed, the formal representatives, residing in the territory under the control of the United Kingdom or the Russian Empire, that is to say: the consuls, vice-consuls, and commercial agents of each of the two contracting parties, were to receive from the local authorities, as a rule, any assistance that could be "legally provided" in the execution of the process of surrendering fugitives from vessels, be they military or merchant. ${ }^{20}$

The Anglo-Russian agreement on trade and shipping contained two important additional ("separate") articles. These articles were considered "so powerful and important as if they were literally brought into [...] treaty."

The first one touched on the issue concerning the rather specific nature of this kind of relations between Russia and the Swedish-Norwegian side. This was due to the fact that the Russians believed that their trade relations with the Kingdoms of Sweden and Norway were "founded on separate conditions [...] not related to general regulations pertaining to foreign trade in force." The hidden motivation behind this were of course the "benefits" and concessions granted in these countries to the Russian-controlled Grand Duchy of Finland. Hence, this additional article was added to the January 1843 agreement, the purpose of which was essentially to avoid, in this respect, the "ambiguities" or "unnecessary disputes" that could arise in British-Russian trade relations. Based on this assumption, both parties agreed that the specific conditions set out above, granted to Swedish and Norwegian trade, could not be applied in any way to the commercial relations and shipping conditions established between Russia and England.

The second additional article to the agreement contained a number of descriptions of exceptions, liberties and privileges which were not to be understood

20 Tygodnik..., no. 34 of 4/18 May 1843, p. 212. 
as infringements of the principle of Russian-British reciprocity in shipping and commercial relations, as adopted in the Treaty of 11 January 1843. Issues such as the following were covered: a) a three-year exemption from vessel fees for ships constructed in Russia and belonging to Russian subjects; b) a three-year exemption from vessel fees for Turkish ships in the Russian ports of the Black Sea, Azov Sea and Danube Delta; such an exemption was only applicable to ships arriving directly from Turkish ports on the Black Sea shores; in addition, such vessels could not carry more than 80 lasts of cargo; $c$ ) the privilege granted to the residents of coastal areas of the Arkhangelsk Governorate, under which they were entitled to import into the ports of said governorate any dried or salted fish free of charge or with only a modest tax; they were also allowed to import selected types of fur; as for exports, the local residents of the Arkhangelsk Governorate were allowed to export grain, ropes, cordage, tar and sailing canvas from their governorate's ports on similar terms; d) a privilege granted by the Tsarist authorities to the Russian-American Company; f) a privilege granted by the Tsarist authorities to the Lübeck Company and the Havre Steam Navigation Company; g) privileges granted by Russian authorities to a number of English Yacht-Club companies in various periods.

For the sake of precision, attention should be drawn to the serious legal turmoil which arose in English-Russian shipping and trade relations with the anticipated outbreak of the Crimean War. Since the period of validity of the treaty formally expired at the end of January 1853, followed by an automatic renewal for the following twelve months, obvious implications in this aspect appeared at the beginning of the war in 1854. This sensitive situation seems to have affected the British side more, at least that is what follows from the fact that already on 20 March 1854, the British Secretary of State for Foreign Affairs at the time, Lord Clarendon, was forced to accept the "Deputation of persons interested in trade with Russia." The delegation sought detailed information from the English diplomat on "the course of action that the English government had decided to take in the case of war" with regard to pursuing trade with Russia, and to the treatment of the property of Russian subjects, present or owning property in the United Kingdom. In the opinion of the guests, the treatment of British citizens and their possessions within the Tsarist empire was directly dependent on the conduct of the British authorities towards Russian individuals and property. ${ }^{21}$ In a reply given on the same day, i.e. 20 March 1854, by Lord Clarendon, the British official indicated first of all that, despite the real threat of war $^{22}$ and the numerous questions in this respect, principally addressed to himself, he could not answer at the given moment otherwise than by quoting the regulations in force in such cases. Moreover, Clarendon,

${ }^{21}$ Tygodnik..., no. 23 of 26 April/7 April 1854, p. 170.

22 The Russian side declared war on the western allies of Turkey, i.e. England and France, on 21 February 1854. 
"relying on his own legal expertise," addressed a personal request to the Deputation visiting him "that [its members] trust that the fervent desire of the British Government is to alleviate, if possible, war disasters and not to cause futile losses to individuals."

Clarendon added that, at the moment of declaration of war on Russia, ${ }^{23}$ the British government intended to announce that Russian ships in British ports were granted a six-week delay for them to pick up all their cargoes and leave the British ports. Moreover, Clarendon also declared full safety and freedom of navigation for the Russian ships encountered on the high seas; however, the condition here was that, on the basis of a review of the documentation provided, the cargoes were proved to have been delivered on board within the six-week period following the formal declaration of war by the United Kingdom.

The Secretary of State for Foreign Policy also pointed out that Russian subjects in the UK "would not be oppressed, either in person or in property." However, in order for the holders of Russian passports to remain safe in England, they had to comply fully with the laws in force and not commit any act illegal for all citizens of the United Kingdom. On the other hand, Clarendon's statement made it clear that the British authorities reserved the right to withdraw the "privileges" of Russian subjects mentioned above in the event that the Russian side did not take similar steps with regard to English citizens residing in Russia.

Finally, when analysing the question of British property remaining within the Russian Empire, which due to various reasons and circumstances had not been removed, Lord Clarendon stressed that these issues were still under consideration by the British government at the time (i.e. it was not decided yet what position to take in this respect). In his view, this problem should be resolved "[...] in a liberal spirit whenever it is proved that the [trade] agreement was concluded in good faith." ${ }^{4}$

Fulfilling the explicit wish of the British Secretary of State for Foreign Affairs, on 1 April 1854, i.e. the day after the formal declaration of war on the Russian side by the United Kingdom, the British Consul "in Sankt Petersburg and its environs," Estland de Michele, addressed the Russian Chancellor of State, Count Nesserlode, with a diplomatic note ("proclamation") "detailing the course of action that the United Kingdom had decided to take in relation to trade with Russia and Russian property in England." 25 The initiative therefore remained in the hands of the British in this respect.

\footnotetext{
${ }^{23}$ Such a declaration was in fact issued on 31 March 1854, i.e. 11 days after the audition.

24 Tygodnik..., no. 23 of 26 April/7 April 1854, p. 171.

25 Ibid., p. 170-171.
} 


\section{Trade and shipping treaty between Russian Emperor Nicholas I and Dutch King William II dated 1/13 September 1846.}

Less than three years after the conclusion of the Anglo-Russian agreement, on 1/13 September 1846, the representatives of the Russian tsar and of the Dutch king, after exchanging their powers of attorney formulated in "due" and "proper" form, concluded a bilateral trade and shipping treaty in Sankt Petersburg along with three "separate articles." ${ }^{26}$ Both monarchs appointed two plenipotentiaries to conduct the final negotiations and conclude the agreement. Tsar Nicholas I appointed Count Karl Robert Nesselrode, presented as the Chancellor of the State (as stated in the preamble), but actually a secret advisor, a member of the Russian Council of State, a recipient of numerous Russian and foreign decorations, a Knight Grand Cross of the Order of the Netherlands Lion. Wilhelm II, in turn, appointed Baron Willem (Wilhelm) Mollerus, ${ }^{27}$ Commander of the Order of the Netherlands Lion, Knight Grand Cross of the Order of the Iron Crown, and at the same time his chamberlain. Significantly, Mollerus was also a Dutch extraordinary deputy and a plenipotentiary minister accredited to the Russian Court.

The final phase of the negotiations was undertaken with a view, as far as possible, to consolidating and extending the mutual "state of friendship and good understanding" and the commercial and navigational relations "so fortunately existing between the two countries and their respective subjects on both sides." The preamble to the treaty also stated that the Mollerus-Nesserlode negotiations had been undertaken with the ultimate aim of finally concluding them, as the talks were of the kind of "arrangements that had long been conducted between the two governments." 28

According to Article 13 of the Agreement, after the ratification of the Treaty by both parties (Tsar Nicholas I ratified the Treaty in Tsarskoye Selo on 25 September/ 7 October 1846), ${ }^{29}$ their respective forms were to be exchanged in Sankt Petersburg within two months from the signing, or even earlier if possible. The Treaty was to remain in force for ten years from the date of exchange of the documents, and then for an indefinite period of time, ending twelve months after either contracting party would notify the other of its intention to repeal the Treaty. ${ }^{30}$

${ }^{26}$ V. N. Aleksandrenko, Sobranie vazhnejshih traktatov i konventsij, zaklyuchennyh Rossiej s inostrannymi derzhavami, Varshava, 1906, pp. 161-165. The Russian-language version of the treaty can be found here.

27 "Willem Baron Mollerus," genealogieonline.nl, available at: https://www.genealogieonline.nl/ stamboom-driessen/I73292905.php [accessed: 21 Dec 2018]. Genealogical information on Baron Mollerus can be found here.

28 Gazeta..., no. 131 of 5/17 June 1847, p. 919-920.

${ }^{29}$ V. N. Aleksandrenko, op. cit., p. 165.

30 Gazeta..., no. 134 of 9/21 June 1847, p. 943. 
Following its hearing at the session of 7/19 May 1847, the Governing Senate in Sankt Petersburg traditionally ordered the publication of the Treaty. ${ }^{31}$ The information about the signing of the treaty was then made public and sent from Sankt Petersburg on 27 May/8 June 1847. In the official "Polish" press the details of the agreement began to be published gradually on 5/17 June 1847, in the $134^{\text {th }}$ issue of Gazeta Rzadowa Królestwa Polskiego of the same date. ${ }^{32}$

The treaty began with the affirmation in Article 1 that Russian and Dutch vessels and subjects would mutually "retain" the freedom to conduct trade and navigate in all parts of the territory of their countries where, at the time of signing, freedom of navigation and trade was in force or where such activity would be authorised in the future in respect of nationals and the merchant fleet of any other nation. The rather general nature of this statement requires the extent of these trade and shipping privileges to be clarified. First of all, it was stated that the subjects of both parties were now granted the unrestricted right to call at the posts, ports and harbours within the possessions of both states; provided, of course, that trade was fully permitted in those places. In order to protect their interests, the Russians and the Dutch were also granted the right to journey and reside in any part of the territories of the contracting states. At the same time, they were provided with identical protection and personal care, as well as the security of their property, that were granted to the locals. This privilege, however, meant an unconditional subordination to local laws and regulations, with particular regard to the commercial and police laws of the host country.

The subjects of the Russian tsar and the Dutch king were not to be subject to any different or higher customs duties, fees or taxes than those which, both customarily and in accordance with the regulations in force, could be imposed (also in the future) on the citizens of the countries enjoying the highest privileged status. This applied to a wide range of activities, whether commercial or industrial, in cities, ports or "any other locations" in both countries.

Moreover, according to this treaty, the Russians and the Dutch were given the same rights as local subjects in administering their property freely throughout the entire territory of the other contracting party, which could be achieved through: a) sale; b) exchange; c) donation; d) legacy; e) or in any other legally permissible manner. The transfer of ownership from one country to another could take place between residents of the Russian Empire and the Kingdom of the Netherlands at the lowest possible cost, since in such cases the transport of said goods was only subject to "deductions or charges" equivalent to those imposed one's own nationals. In the event of the death of a Russian or Dutch subject within the territory of the other signatory country, when no relatives of said subject were present there,

\footnotetext{
31 Polnoye Sobranye Zakonov Rossiyskiy Imperii, Sobranye Vtoroye, vol. 22: 1847, Sankt Petersburg, 1848 , p. 431.

${ }^{32}$ Gazeta..., no. 131 of 5/17 June 1847, p. 919.
} 
the local consul of their country of origin (or even, in the absence of such a person residing at a "reasonable" distance from the place of death, a representative of the local authorities) was obliged to "temporarily administer" their estate under exactly the same conditions as would apply in the event of the death of a local citizen. This "temporariness" lasted until the legal heir would undertake appropriate legal measures to formally take over the estate. It was clear, however, that any inheritance disputes should still be settled at all levels of jurisdiction in accordance with the rights and by the courts of the country in which the inheritance was opened.

Article 4 of the Agreement stipulated that Dutch citizens could choose freely whether to directly engage in commercial or industrial activities in Russia or to appoint representatives for that purpose. Therefore, they could freely and unrestrictedly choose and designate their factors, brokers and agents. The new law guaranteed that the subjects of the Dutch king did not need to pay any fee or salary to those individuals that had not been appointed by them personally as their representatives. At the same time, in each case of concluding a commodity contract, full and unrestricted liberty was guaranteed as to the conditions of purchase and sale and the adoption of said prices for each Russo-Dutch contract relating to import or export from Russia. ${ }^{33}$ One exception, however, was the situation when, in accordance with the laws and customs in force, the presence or brokerage by some (commercial) agent was required when concluding a given contract. It goes without saying that the new agreement also guaranteed the Russian subjects the same privileges "in the countries of the Most Serene Dutch King." 34

The issue of appropriate "treatment" of maritime transport appeared in the Treaty of 13 September 1846 by virtue of its Article 5, where it was underlined at the beginning that both Dutch vessels calling at and leaving ports of the Russian Empire proper and of the Grand Duchy of Finland, and Russian vessels calling at and leaving Dutch ports, should be treated by local authorities in the same way as their own vessels, i.e. "national" or "domestic." This was the case regardless of where the ships had come from and whether they were loaded with cargo / ballast or not. In terms of the payment of the following fees collected in the name and on behalf of the State administration, national officials or associations and institutions: a) ship fees, b) flag fees, c) port fees, d) anchoring fees, e) rafting fees, f) towing fees, g) crane fees, h) sluice fees, i) channel fees, $\mathrm{j}$ ) quarantine fees, $\mathrm{k}$ ) storage fees, and $\mathrm{l}$ ) any other financial charges of a similar nature, it was decided that the vessels having called at one port belonging to a signatory state and subsequently travelling to one or more ports of the same state, would be exempt from paying vessel fees in those ports. The above occurred when: a) the ship called at some port to deposit its entire cargo, b) to collect cargo, c) or to replenish it. The said

\footnotetext{
33 Ibid., p. 920.

${ }^{34}$ Ibid., p. 921.
} 
exemption was, of course, only applicable upon proof that such fees had already been paid at the first port of call.

The ships which entered one of the ports under the jurisdiction of the other contracting party "out of necessity" did not have to pay any vessel or shipping fees. The condition imposed here was that ships forced by unforeseen circumstances to call at any port of the other contracting party, along with with their cargoes, would leave without "the slightest unloading or commercial activity." However, the unloading and reloading of goods for the purpose of repairing the ship did not count as such. Similarly, the transfer of cargo to a second ship in case when the first ship was found not to be seaworthy would not be considered as such either. Under the provisions of the agreement of 13 September 1846, the notion of "commercial activity" did not include spending money on providing the crew with necessary food. ${ }^{35}$

The agreement also ensured full equality in terms of charges for exported and imported goods, both to and from Russia, as well as to and from the Netherlands. This was first stated with regard to Dutch vessels, both a) those entering Russian ports (or ports in the Grand Duchy of Finland) directly from the Netherlands or from any other place/country, and b) those leaving the ports of the Russian Empire, claiming that any goods carried by those vessels, regardless of their origin, could only be subject to identical charges as those levied on the same goods imported or exported, or possibly in transit on Russian vessels. Subsequently (as described later in the same Article 6), identical rules also applied to Russian vessels importing and exporting goods to the Netherlands. ${ }^{36}$

The significant privileges guaranteed by the Treaty of 13 September 1846 to the Dutch side also resulted in the Kingdom of the Netherlands granting the Russian side certain privileges that are quite unusual in relations with other countries. This was done particularly in view of: a) the Dutch vessels being granted free access to Russian and Finnish ports, irrespective of the place of departure of the vessel and the type of cargo carried on board, while only having to pay the same fees as those imposed on vessels under the Russian ensign; b) "the advantages conferred in this respect on Dutch trade by the current treaty."

The above-mentioned additional rights granted to the Russians consisted in five fundamental issues. The first one involved granting Russian ships and subjects the right to conduct quay trade throughout the entire European territory of the Kingdom of the Netherlands, under the conditions and rules applicable to Dutch subjects. This special privilege additionally included unrestricted access to all Dutch sea ports, which from now on would be fully "open" to Russians. At the same time, the document clearly indicated that no reciprocity would be accorded to Dutch subjects and vessels at the coasts or ports of Russia or the

35 Gazeta..., no. 132 of 6/18 June 1847, p. 926.

${ }^{36}$ Ibid., p. 926-927. 
Grand Duchy of Finland for this reason. Secondly, the Dutch agreed that Russian vessels arriving from any port of the Russian Empire, loaded with cargo consisting at least in 50\% of: a) hemp; b) flax; c) wood; d) wood tar, or f) tar, would enjoy a $20 \%$ reduction in rafting fees at Dutch ports, paid in accordance with the general fares applicable to domestic vessels.

Thirdly, the Dutch side agreed that the permanent import tax of two guilders per last of grain be reduced by $10 \%$ for grain imported into the Netherlands from Russian and Finnish ports on ships of both contracting parties.

In the fourth special privilege, Dutch King William II agreed to adopt, in the process of introduction of Russian crops and industrial goods into the Dutch territory, the principles customarily applied to the countries enjoying the most privileged status (including both prerogatives already granted and those that could be granted to other privileged European nations). Moreover, the Dutch side confirmed that the Russian ships would enjoy the same conditions "in all respects" in the Dutch settlements as the ships of any other nation enjoying privileged status. This declaration was to be valid during the entry, stay and departure of these ships, regardless of their port of origin, and whether or not they had ballast. ${ }^{37}$

And finally, Wilhelm II committed himself in Article 7 of the Treaty of 13 September 1846 to grant Russian ships in the future all the same privileges and "benefits" that could be granted to other countries in respect of "intermediate shipping" without additional charges and without any restrictions. This privilege was to apply even if specific concessions were granted to some country "in onerous conditions," but with the restriction that in such a case the above first three concessions would be declared inapplicable. ${ }^{38}$

Tsar Nicholas I, on the other hand, declared that in the selected situations defined in Articles 5 to 7 of the treaty, the provisions of his Edict of 19 June 1845 (referred to in the first part of the present article) were not applicable in trade and maritime relations with the Netherlands. Therefore, the tsar's act in question could not be applied in the context of direct or indirect trade between the Dutch and the Russians, nor did it have the slightest impact on Dutch direct or indirect shipping. Wilhelm II, in turn, ensured that the premiums, refunds and other similar concessions and financial refunds granted to his own national vessels in respect of import and export would also be applied in respect of direct Russian imports or exports on board vessels flying the Imperial ensign.

The crucial issue of ascertaining the nationality of the ships involved in trade between Russia and the Netherlands was solved by the decision to carry out the verification procedure "jointly" based on the laws and regulations of both countries, using documents issued by the competent authorities to: a) the shipowners; b) the captains; or c) the skippers.

\footnotetext{
37 Ibid., p. 927.

38 Ibid., p. 927-928.
} 
In turn, the Dutch and Russian subjects' rights were fully aligned in both countries in all matters concerning: a) anchoring and storing the vessels; b) loading and unloading the vessels in ports; c) the use of port basins; d) bays; e) or harbours, situated on rivers and canals located in the territories of the contracting parties. Ships of both nationalities could leave their berth completely freely and without any hindrance after each loading or unloading of their cargo, while the local authorities had to ensure that no delays be allowed when issuing and returning passports to ship's captains. A possible delay in returning such passports was only possible in two cases. The first one was when a judicial inquiry had to be carried out on board the given vessel. The second exception occurred when, because of financial claims made against the crew by public administration or private individuals, or because of offences committed by anyone from the vessel's crew, the departure of the ship had to be postponed until the matter was fully clarified. ${ }^{39}$

No additional (or higher) charges or customs duties, other than those already levied or to be levied on similar products, but originating in other countries, could be imposed in either country and its dependent on the import of crops or industrial goods of the other contracting party. The same principle was to be respected reciprocally and in respect to exports of crops and industrial goods from both countries. However, a provision was included in the agreement to the effect that a possible ban on the import or export or transit of any goods or crops could only be imposed if it was extended to similar products or crops originating in other countries.

These solutions were complemented by a bilateral assurance that, in the field of trade, customs and shipping, third parties could be granted only such "advantages, privileges and liberties" that would also be guaranteed for the subjects of the other contracting party of the Treaty of 13 September 1846. Depending on whether the relevant concession was granted free of charge or in return for payment, similar principles and obligations were to be applied in the Russo-Dutch trade relations; the compensation applied had to be adequate as much as possible. ${ }^{40}$

An even more detailed clarification of the principle of "mutual equality" was provided for in Article 12 of the Agreement, stressing the common obligation to avoid the emergence of inequalities in the treatment of the ships of both countries in the process of purchase of cargo ("products or other commercial objects") on board these ships. For this purpose, the Russian Empire and the Kingdom of the Netherlands agreed not to accord priority or greater importance to items carried on board domestic vessels: a) either indirectly by administrative means, b) either acting through companies or associations engaged in activities on behalf of the state concerned or under its authority, c) or through particular agents. ${ }^{41}$

39 Gazeta..., no. 133 of $7 / 19$ June 1847, p. 934.

${ }^{40}$ Ibid., p. 934-935.

${ }^{41}$ Ibid., p. 935. 
As usual, the treaty also covered issues relating to the treatment of "extraordinary cases." In the event of a naval or merchant ship of the other contracting party crashing or sinking, the signatories of the agreement undertook to provide the same extent of assistance as if it were their own vessels. The ships that were involved in accidents or shipwrecks and their parts, and everything that belonged to the equipment of said ship, as well as its food supplies, and all objects and goods salvaged from the sea (as well as money acquired through the sale of goods recovered from the sea) were considered "untouchable." The Act of 13 September 1843 literally stipulated that all these ships and their parts, as well as the recovered goods and objects, etc., would be "unquestionably handed over to their owners or their representatives," provided, however, that the latter proved the legitimacy of their ownership. If, during the occurrence of a specific incident, the owner of the vessel concerned, or at least his representatives, were not at the scene of the incident, the assets described above or the proceeds from their sale, as well as all the documentation recovered from the shipwrecked vessel, had to be deposited with the local Dutch or Russian consul in whose jurisdiction the incident occurred. These consuls, shipowners and, where appropriate, their representatives, were obliged, however, to cover the costs of "salvaging" the ship in question. In addition, a "tax" (price list fee) was usually paid in a given country for the "salvaging" of a vessel in the event of a disaster. A common position was also adopted to the effect that goods recovered from the sea were not subject to any customs duties unless they were used following their return.

With reference to the matter of handling special cases, the signatories of the agreement of 13 September 1846 also raised, in Article 14 of the document, the issue of their formal representations engaged in the legal protection of their shipping and commercial activities. As a result, both parties were granted the right to send their freely appointed consuls, vice-consuls and commercial agents to the territory of ports and municipal entities of commercial nature. They were also provided with "privileges, power [and] exemptions" which, as a rule, were granted to consuls, vice-consuls and agents of countries enjoying the highest privilege status. The document also covered the scenario where any of the consuls, etc. decided, in spite of fulfilling their formal duties, to engage in shipping and commercial activities themselves. In such case, this representative of Russia or the Netherlands was, as a rule, subject to the laws and customs that were in force, in terms of conducting trade activities, for individuals originating from the country they represented, or from another country enjoying the highest privileged status. Particular attention was paid to the status of a consular agent residing in a port or commercial city of the other contracting party from among the latter's local citizens. In such case, that person, despite holding the position of a foreign consul (agent), did not cease to be considered as a subject of their country of birth by the local authorities. As a result, said person was subject to all local laws and regulations in force in the place of their activity. However, such dependence could not in any way limit 
the scope or effectiveness of the exercise of their duties, nor could it expose the archives of the consulate to the risk of status of untouchability. ${ }^{42}$

Dutch and Russian consuls, vice-consuls and commercial agents were empowered to request support and assistance from local authorities in order to possibly lead to the detection, capture, arrest or imprisonment of sailors or any other individuals who had fled from naval or merchant ships of their country. In order to effectively obtain support in such a difficult and "sensitive" matter, however, they first had to travel in person to the seat of the competent judicial authorities or to the places of residence of judges and civil servants, bearing a formal written request for the surrender of the fugitives. Such a petition had to be supplied with relevant ship registers (crew lists) or any other official documentation proving that the individuals in question were in fact part of the crew of the ship. Only a demand supported by such evidence and certificates could, according to the Treaty of September 1843, attain the intended result.

The subsequent procedure after the arrest of the fugitives from a ship of the other contracting party consisted primarily in their detention, at the request of consuls, vice-consuls or commercial agents, in public prisons. The costs of accommodation and meals were covered by "whoever demanded their surrender." The purpose of this practice was to keep the captured fugitives in custody until they could be returned to the ships to whose crews they formally belonged. The second possibility was to send the fugitives directly back to their country of origin, which could be done either on a ship of the deporting state or that of any other country. The detained fugitives could not, however, be imprisoned indefinitely. If, within three months from their arrest, they were not sent back to their country of origin, they regained their freedom. The principle of double jeopardy was also observed in this matter.

However, should a particular fugitive be found in the meantime to have committed any offence in the country of his detention, then the release of the fugitive would be suspended until the local court considered the charge and a sentence was passed. In general, fugitives were not surrendered either if it was found that they were subjects of the country in which they had committed the desertion.

Finally, the Russo-Dutch treaty on trade and shipping unexpectedly included a provision extending the special rights granted to various English yacht clubs in the Russian Empire to similar Dutch associations. For their part, the Russians ensured that their equivalent associations enjoyed the same prerogatives in the territory of the Kingdom of the Netherlands as those granted to the British yacht clubs there. ${ }^{43}$

In their first two parts, concerning privileges and exemptions granted to the Russian side, the additional articles attached to the main treaty ("separate articles")

${ }^{42}$ Gazeta..., no. 134 of 9/21 June 1847, p. 941-942.

43 Ibid., p. 942. 
did not differ in their content from the similar arrangements concluded in 1843 during the signing of the treaty on trade and shipping with Great Britain. The case was different for the third additional article. Here it was stated expressis verbis that two specific privileges "shall not be considered derogatory to the rules of reciprocity serving as a principle of this treaty." The first of these was the general guarantee that possible new prerogatives could be freely conferred by the Dutch authorities in the future on their own nationals: a) "to encourage the building of merchant vessels in the country" b) or to speed up or initiate the process of development of a particular branch of the shipbuilding industry of their choice. The latter contained a similar reservation in respect of any legal, commercial and economic concessions granted by the national authorities to Dutch steam shipping companies. ${ }^{44}$

\section{The Declaration on the Equal Rights of Russian and Tuscan Merchant Ships in Russian Ports and Tuscan Possessions of $29 \mathrm{March} / 10$ April 1847.}

The last major trade and maritime agreement described here, concluded by the Russian Empire in the period preceding the advent of the Spring of Nations, was the one signed with the Grand Duchy of Tuscany. With the permission of Tsar Nicholas I, on $28 \mathrm{March} / 9$ April 1847, the Russian Chancellor for Foreign Affairs, Count Nesselrode, signed a declaration on "the equal rights of Russian and Tuscan merchant ships in Russian ports and Tuscan possessions." This declaration "was to serve in place of a formal treaty," equivalent in the force of its provisions. ${ }^{45}$

After the declaration was signed by the Tuscan Foreign Minister, Count Luis Serristori, ${ }^{46}$ it was transmitted to Nesserlode, who exchanged the ratified texts on $2 / 14$ May 1847 . This agreement was confirmed on the Russian side not only by Nesselrode's signature itself, but also, which was indispensable in this situation, by the seal of the Russian Ministry of Foreign Affairs. Subsequently, the head of the Ministry of Justice in Sankt Petersburg, Count Panin, submitted the translated text of the agreement to the Governing Senate in order to make it public. After the

44 Gazeta..., no. 135 of 10/22 June 1847, p. 950.

45 Gazeta..., no. 260 of 11/23 November 1847, p. 1991-1993.

46 Correspondence Respecting the Affairs of Italy 1846-1847. Presented to Both Houses of Parliament by Command of Her Majesty, London 1849, p. 283. Major General Count Luis Serristori was Commander of the Order of Saint Joseph, Knight Second Class of the Order of Saint Anna, Knight Fouth Class of the Order of Saint George, and Knight of the Order of Saints Maurice and Lazarus. He was also decorated with the Medal of the Turkish War of 1828-1829. At that time, Serristori was not only Minister of Foreign Affairs of the Grand Duchy of Tuscany, but also Counsellor of State for Finance and War, and Director of the War Department. In 1842 the second edition of his well-known Statistica dell'Italia, printed by Stamperia Granducale, was published in Florence. 
appropriate information was sent out from Sankt Petersburg on 1/13 November 1847, the content of the agreement was published in the formal "Polish" press, by the Gazeta Rzadowa Królestwa Polskiego, issue 260, dated 11/23 November 1847. ${ }^{47}$

With the mutual consent of both governments, the antedated agreement, set for an eight-year duration, came into force on 1/13 January 1846, although this was rather connected to the date of opening of shipping at the turn of winter and spring of 1846 . The rationale behind this solution was the fact that, in practice, the "equality" of the ships of the two countries had since then been fully respected by both parties to the agreement. The formal assumption was that after eight years from the formal date of the beginning of the agreement, i.e. on 31 December 1853 , the provisions of the agreement were to be respected automatically for an unspecified period of time. The only chronological limitation was the possibility of terminating the declaration by one of the parties. In that case, the agreement was to remain in force only for a period of twelve months from the date of such notification. ${ }^{48}$

The text of the agreement itself contained in its preamble the information that Count Nesselrode has signed the Russian version of the agreement only after having received assurances from the Ministry of Foreign Affairs of the Grand Duchy of Tuscany (Leopold II originated from the House of Habsburg-Lorraine $)^{49}$ that "no additional shipping fees or customs duties, nor any other special charges," other than those normally imposed on domestic Tuscan vessels, were levied on vessels flying the Russian ensign in Tuscan ports..$^{50}$

Article 9 of the declaration indicated that the solutions introduced had full force of law in all ports of the Russian Empire that were considered trade centres authorised to conduct international trade. They also applied in the ports of the Grand Duchy of Finland. The indisputable reservation here was the obligation to respect full reciprocity in the treatment of Russian ships in the territories of the Grand Duchy of Tuscany. ${ }^{51}$

Article 1 of the Russian version of the agreement therefore provided that within the ports under the authority of the Russian Empire (however without mentioning the Grand Duchy of Finland literally at this point), vessels flying the Tuscan ensign and carrying any cargo or ballast shall be treated during their arrival, stay and departure in a manner identical to that of "domestic," i.e. Russian vessels. This pertained in particular to the levying of local port and navigation charges, i.e.: a) ship fees, b) lighthouse fees, c) rafting fees, d) anchoring fees, e) quarantine

47 Gazeta..., no. 260 of 11/23 November 1847, p. 1991-1992.

48 Ibid., pp. 1991 and 1993.

49 "Leopold II, Grand Duke of Tuscany," Encyclopaedia Britannica, available at: https://www.britannica.com/biography/Leopold-II-grand-duke-of-Tuscany, "His Imperial and Royal Highness" Leopold II the Great was the ruler of the Grand Duchy of Tuscany from 1824 to 1859.

50 Gazeta..., no. 260 of 11/23 November 1847, p. 1991.

51 Ibid., p. 1993. 
fees, f) administrative charges, g) and any other financial charges or "obligations" imposed under any other name. Naturally, in order to avoid possible misunderstandings, the legislator did not fail to point out that this applied to charges levied on behalf of (or for the benefit of) the Tsarist administration, local authorities, or even private institutions.

Moreover, Tuscan ships thus gained the right to import and export all kinds of goods and objects, irrespective of their origin, to and from Russian ports, as well as to put them into storage there within the scope of the trade circulation permitted in the Russian Empire. As a standard, such operations were to be carried out without having to pay customs duties or financial charges other than those levied on the same goods or products imported or exported on vessels flying the Russian ensign. Similarly, the vessels of the Grand Duchy of Tuscany also benefited from premiums and custom duty refunds within the ports of the Russian Empire, and possibly other similar commercial and financial concessions already reserved or planned to be reserved in the future for Russian vessels, both on the export and on the import of goods.

All these privileges and exemptions reserved by the Declaration of 10 April 1847 for the Tuscan fleet and its cargoes were applied in full regardless of the port of origin. Thus, they could enter Russia either directly from Tuscany or from third party ports. Similarly, their final destination, i.e. whether after visiting the ports of Tsarist Russia, Tuscan vessels decided to sail to their home country or head for other countries, did not matter. At the same time, Article 4 of the agreement mentions the lack of the slightest differences in the mutual treatment by Russians and Tuscans of possible shipping and trade fees imposed on ships in the case of "direct" and "indirect shipping."

In view of these mutual concessions and benefits, the Russian side decided, of course, to exempt Tuscan ships and their cargoes (as it had been done in the agreement with the Netherlands) from the validity of Articles 2 and 3 of the Decree of 19 June 1845, imposing strictly defined freight and "excess material" fees on commercial vessels of countries that did not enjoy the highest privileged status. It was also clear that although the scope and nature of this entire range of Russian-Tuscan concessions was essentially broad, it did not include Russian coastal shipping, which the Russian Empire "reserved exclusively to domestic vessels." 52

As for incidents of an "extraordinary nature," the Declaration of 10 April 1847 guaranteed Tuscan ships the right to call at ports under Russian control, where every ship flying that ensign could seek refuge in the event of a (violent) storm or other dangerous circumstances. Upon arrival in one of the Russian ports, a damaged vessel of the Grand Duchy of Tuscany was entitled to carry out repairs there and to purchase the necessary items and goods. When the vessel was leaving, neither the harbourmaster nor any administrative authority could

52 Ibid., p. 1992. 
impose on such a vessel any port or shipping charges traditionally paid under any name to the Tsarist government. However, these exemptions and guarantees applied only under the condition of a clear confirmation that the reasons which forced the Tuscan ship to suddenly enter one of the ports of the Russian Empire were "substantial and obvious." Moreover, the crew of such a ship seeking refuge could not, during their stay in a Russian port, carry out any commercial activity during the possible unloading and reloading of their goods. Another imperative condition was that such a damaged ship should not remain in the port longer than actually necessary.

On the other hand, the unloading or reloading of goods with the aim of facilitating the effective repair of the ship could not be regarded as a commercial activity. The declaration also expressed a similar view with regard to the purchase of food for the crew of the ship under repair. By contrast, should it become necessary for the captain of the ship to raise funds to cover the costs of the repairs by selling a particular group of goods on board, he was obliged to comply fully with the provisions and scope of the tariff charges in force in the port where the ship had landed. ${ }^{53}$

In the event of shipwreck, sinking or serious damage suffered by Tuscan ships along the Russian shores, the Tsarist authorities guaranteed, pursuant to Article 8 of the Declaration, covering their entire crews (and, of course, the vessels themselves) with the same care as would be provided to Russian crews and ships in a similar situation.

A wrecked or damaged vessel and all goods carried on board (as well as possible proceeds from their sale) were to be returned to their rightful owners or "to whom they belonged instead." It was however necessary to pay a portion of the value of the ship or goods in the form of a "finder's fee," or rather a "salvage fee," which was also paid in all similar cases by the owners of wrecked Russian ships. Further analysis of the declaration showed that the goods rescued from the sea were not subject to other charges or customs duties, except in cases where they were "suitable for use." ${ }^{54}$ It was understood that all these privileges and "benefits" were granted to Tuscany by the Russian Empire on the basis of full reciprocity.

\section{Conclusion}

The signing of a number of trade and shipping treaties and declarations by Tsarist Russia in 1843 and 1846 was undoubtedly an indication of a new direction in the state and economic concepts of the Russian Empire. Their aim was undoubtedly to stimulate trade (in goods and crops) between Russia and Europe. This initiative, which very soon was halted by the events of the Spring of Nations, followed by

\footnotetext{
53 Ibid., p. 1992-1993.

54 Ibid., p. 1993.
} 
the Crimean War, would be continued again with the signing of new trade and shipping agreements since 1857.

Of course, the above treaties and declarations differed from one another, both in detail and in the extent of the directly visible and verbal cordiality (or lack thereof) in mutual relations. The latter can be seen by comparing the agreements concluded with England and the Netherlands; the former when these two treaties are compared with the declaration co-signed by the Grand Duchy of Tuscany. The juxtaposition of these details will certainly allow the researchers involved to examine them more closely. From the Polish point of view, it is important to emphasise the terminology used in the treaty with England to ensure trade with the areas of the former Commonwealth, with the document referencing only estuaries of large rivers beyond the control of the Tsarist state.

It is tempting, of course, to ask the question whether the transformation process started so abruptly in 1843 could have had a chance of success in the context of the quasi-feudal economic structure in Russia at that time. Answering this question would be hard, if not impossible. However, when analysing the entire issue, it is possible to put forward a surprising hypothesis. In the author's opinion, the "treaty-based campaign" of revitalising Russia's trade relations with Europe (apart from its obvious economic aspect) was mainly intended to modernise the country via "external means," i.e. through participation in lively foreign trade, which in turn would automatically impose, by way of competition, the automatic modernisation of the state. In so doing, the remodeling of the state, which appeared indispensable and obvious in the 1840s even for the Sankt Petersburg elites, was pursued through economic revival, rather than through a reform of the social structure (i.e. the emancipation of the peasants), which Nicholas I wholeheartedly opposed. In this sense, this activity in the area of maritime trade undertaken just before the beginning of railway construction in Russia was the last attempt of the quasi-feudal Tsarist Russia to maintain the internal status quo.

\section{Abstract}

In order to increase the participation of the Russian Empire in international trade circulation, the Russian authorities decided in the 1840s to sign a number of international agreements of a commercial or navigational nature. These treaties include, among others, the agreements detailed in the present article, concluded with the governments of Great Britain, the Netherlands and the Grand Duchy of Tuscany. The first of the above agreements was concluded with England, which took place on 11 January 1843. Subsequently, the Russians signed trade and shipping agreements with the Netherlands (13 September 1846) and Tuscany (10 April 1847). In practice, these treaties conferred on both contracting parties the status of their most privileged partners in their economic activities. According to the author of the text, the revival of Russia's commercial relations with Europe was intended to achieve the modernisation of the Tsarist empire through participation in foreign trade, which would in turn boost, by way of competition, the modernisation of the state. 


\section{Bibliography:}

A. F., Kulibin S., Kankrin Graf Yegor Francovic, Rosskiy Bibliografitseskiy Slovar, Ibak-Klucarev, Sankt Peterburg, 1897.

Aleksandrenko V. N. Sobranie vazhnejshih traktatov i konventsij, zaklyuchennyh Rossiej s inostrannymi derzhavami, Varshava, 1906.

Central Archives of Historical Records, fond of the Administrative Council of the Kingdom of Poland, file 22.

Correspondence of Sir Charles Stuart, Baron Stuart de Rothesay (1779-1845), Edinburgh University Library Special Collections, ref. GB 237 Coll-509, Administrative / Biographical History, available at: https://archiveshub.jisc.ac.uk/search/archives/84857947-0af8-3dc08f71-e6a88b04e7a2 [accessed: 30 Dec 2018].

Correspondence Respecting the Affairs of Italy 1846-1847. Presented to Both Houses of Parliament by Command of Her Majesty, London, 1849.

Henderson, T. F., "Rothesay Stuart Charles (1779-1845)," Dictionary of National Biography, vol. 55, London, 1898

Gazeta Rządowa Królestwa Polskiego, no. 131 of 5/17 June 1847.

Gazeta Rządowa Królestwa Polskiego, no. 132 of 6/18 June 1847.

Gazeta Rządowa Królestwa Polskiego, no. 133 of 7/19 June 1847.

Gazeta Rzadowa Królestwa Polskiego, no. 134 of 9/21 June 1847.

Gazeta Rządowa Królestwa Polskiego, no. 135 of 10/22 June 1847.

Gazeta Rzadowa Królestwa Polskiego, no. 260 of 11/23 November 1847.

"Leopold II, Grand Duke of Tuscany," Encyclopaedia Britannica, available at: https://www.britannica.com/biography/Leopold-II-grand-duke-of-Tuscany.

Lorentz J. A., Schmitt R. T., Volkner A. G., Count Georg Cancrin and the history of cancrinite discovery, http://www.minbook.com/site_files/16-2-en-Page24-25.pdf [accessed: 11 Jan 2019].

Martens F. F., Recueil des traités et conventions conclus par la Russie avec les puissances étrangères, vol. 4, part 1: Traités avec L’Autriche 1815-1849, Sankt Petersburg, 1878.

Martens F. F., Recueil des traités et conventions conclus par la Russie avec les puissances étrangères, vol. 12: Traités avec l’Angleterre 1832-1895, Saint Petersbourg, 1898.

Matrens F. F., Recueil des traités et conventions conclus par la Russie avec les puissances étrangères, vol. 15: Traités avec La France, Sankt Petersburg, 1909.

M. Poleskov, Nesselrode Karl (Karl Robert) Vasilievits, Rosskiy Bibliografitseskiy Slovar, NaakeNakenskiy - Nikolai Nikolaevich Starsiy, Sankt Peterburg, 1914.

Polnoye Sobranye Zakonov Rossiyskoi Imperii, Sobranye Vtoroye, vol. 21: 1845, Sankt Petersburg, 1846.

Polnoye Sobranye Zakonov Rossiyskoi Imperii, Sobranye Vtoroye, vol. 22: 1847, Sankt Petersburg, 1848.

Rutkowski M., "Handlowe i nawigacyjne konwencje rosyjskie zawarte z Turcją i Austrią w roku 1846," in: Odessa i Morze Czarne jako przestrzeń literacka, ed. J. Ławski, N. Maliutina, Białystok-Odessa, 2018, pp. 158-177.

Tygodnik Petersburski. Gazeta Rządowa Królestwa Polskiego, no. 45 of 16/28 June 1842.

Tygodnik Petersburski. Gazeta Rządowa Królestwa Polskiego, no. 30 of 20 April/2 May 1843.

Tygodnik Petersburski. Gazeta Rządowa Królestwa Polskiego, no. 32 of 27 April/9 May 1843.

Tygodnik Petersburski. Gazeta Rządowa Królestwa Polskiego, no. 34 of 4/18 May 1843.

Tygodnik Petersburski. Gazeta Rządowa Królestwa Polskiego, no. 23 of 26 March/7 April 1854.

Marek Rutkowski, dr hab., independant historian, Białystok (rutmarek@gmail.com) 